\title{
Fiscal management on revenue-based or expenditure-based adjustments: an empirical evidence from EU-Countries
}

\author{
Ramona-Mihaela BÂZGAN \\ The Bucharest University of Economic Studies, Bucharest, Romania \\ bazgan.ramona.mihaela@gmail.com
}

\begin{abstract}
An objective for each developed state remains the improvement of a suitable fiscal management system that could generate an increased level of resources. Further on, planning, distributing, allocating those resources to the proper beneficiaries, could generate an economic stabilization, suitable economic growth, decreased level of the net lending variable. The study consisted in an empirical research throughout it was developed the analysis of the impact of fiscal strategies and public expenses adjustments on economic growth and budgetary balance. Time series data from 1998 to 2018 were used on the empirical evidence over the European countries. The study developed an econometric model represented by an unbalanced panel data analysis having as independent variables: the variance of direct taxes, the dynamics of indirect taxes, the variance of budgetary balance, the variance of tax burden, the dynamics of change in net lending as percent of gross domestic product. The dependent variable was revealed throughout the variance of gross domestic product per capita. Over 588 time series observations and 28 cross-section data were taken into consideration in order to reveal if either revenue-adjustments or public-spending adjustments had a greater influence on the evolution of economic growth over the EU-Countries. The result of the econometric model exposed a positive correlation between total expenditure, budgetary balance and economic growth and a negative correlation between direct taxes, indirect taxes, tax burden and economic growth. Moreover, by generating dummy variables on the fixed effect model, it was revealed that large fiscal improvements had a less positive effect on the development of economic growth than fiscal adjustments based on medium-size consolidation.
\end{abstract}

Keywords: euro zone, unbalanced panel data, fixed effects, fiscal adjustment, dummy variables, expenditure-based adjustment, revenues based-adjustment.

Please cite the article as follows: Bâzgan, R.M., (2019), „Fiscal management on revenue-based or expenditure-based adjustments: an empirical evidence from EU-Countries", Management \& Marketing. Challenges for the Knowledge Society, Vol. 14, No. 1, pp. 163-175. DOI: 10.2478/mmcks2019-0011.

\section{Introduction}

Fiscal management system based on suitable fiscal policies adjustments would consist into a proper distribution of the public resources and further on to a sustainable economic growth for each economy from a developed country. Fiscal adjustments implemented through any changes in the level of taxes, in the dynamics of public spending or in a mix up between them would consist in a higher probability of public debt stabilization. Recent econometric research analyzed the improvements made over fiscal policies along with the consequences for generating a positive impact in the evolution of economic growth. For decreasing the level of budgetary balance, public authorities would have to determine which 
fiscal management strategies to implement, whether to decrease the level of expenses or to increase the level of public revenues. Any change in the dynamics of public spending or in the level of tax revenues could be considered a contractionary or expansionary strategy. Public spending could reach a raise in the value as a consequence of an increase in the dynamics of public deficit. There were developed a lot of research studies in which it was demonstrated what types of strategies to be implemented by developed countries during a period of recession in order to decrease the level of public deficit. If public strategies implemented by the states are considered expansionary or contractionary remain a sustained actual research. This study made a review on the public strategies implemented by the public administration from the European states in the last years. It was revealed whether expenditure-based adjustments or revenue-based adjustments could be determined and implemented on economies from European states. Time series data from Ameco macroeconomic database was used to collect the past values of the variables and to determine the causality between variables which further could direct to a decision on which types of strategies to be implemented in the future. The study took into consideration large improvements recorded on public deficits and researched what effects these strategies had on the entire economy or on the dynamics/ evolution of debt or GDP per capita.

Part 1 includes the relevant literature with reference to the econometric models which can explain the impact of public-revenue adjustments or expenditure-based adjustments on the economic growth or on the budgetary balance.

Section 2 reveals an overview on time series data retrieved on European countries over the period of 1998-2018. Section 3 reveals the methodology of the fixed effect panel model and section 4 concludes on how the states could implement a suitable fiscal management system whether on revenue-based improvements or expenditure-based adjustments.

\section{Literature review}

Recently, as consequences of the financial crisis, due to the high level of budgetary balance, adjustments were implemented among the fiscal strategies performed over economies from developed countries. Fiscal management based on which types of fiscal policies strategies could generate a sustainable economic growth represents a continuously analyze in recent empirical studies. First of all we tended to focus on econometric studies which revealed the medium or long-run causality between public revenues and public spending. Secondly, we made a research on studies which exposed the correlation between fiscal adjustments made in the dynamics of public revenues, the adjustments made in the distribution of public expenditure and their impact on the level of budgetary balance and economic growth. On the last part of literature review a research on studies which determined the definition of a suitable fiscal adjustment was implemented.

The causal relationship between public revenues and government spending represents a continuously research implemented on econometric models. Friedman (1978) under a research concluded that increasing the level of public revenues generate an increase in the government expenditure causing in this way a high level of budget deficit. Therefore, 
public revenues have a positive causality to government expenditure. A unidirectional causality from expenditure to revenues was developed under the studies developed by Wagner (1977), Wiseman (1979) and recently Niskanen $(2002,2006)$ under which was concluded that public authorities through government have first to increase the expenditure and then consecutively the level of public revenues would increase.

Regarding the impact of revenue-based adjustments and expenditure basedadjustments on economic growth or on the public debt, most empirical research concluded that changes in the level of public expenditure distribution in favor of any change in the level of taxation would improve a higher economic growth. Molnár (2012) on a research found out that spending-based adjustment versus revenue-based one are more likely to stabilize the level of debt. Even so, if the accent mark would be on the side of expenditure-based adjustments, the debt would stabilize over a short-term period not over a long-term period. Based on revenue driving side, if the trend would consist on changes in the structure of business taxes these would have temporary stabilization on debt. Fiscal politics are associated with fiscal expenditure consolidation episodes that are relevant in the stabilization of debt. Also, while the analysis confirms that spending-driven adjustments versus revenue-driven ones are more likely to stabilize debt, it also reveals that large consolidations need multiple instruments for consolidation to succeed. Alesina and Ardagna (2010) made a study over time series data from OECD Countries over the period of 1970 2007 and determined that fiscal variations based on cutting the level of taxes are more likely to increase growth than those based on spending increases. Fiscal adjustments based on spending cuts and no tax level increases are more likely to reduce deficits and debt over GDP rations than those based on tax increases. Adjustments on the spending side rather than on the tax side are less likely to create recessions. Tax cuts are more expansionary than spending increases. It was also revealed a negative correlation between spending and tax increases on GDP growth. Mountford and Uhlig (2009) under a vector autoregressive model determined that deficit financed by tax cuts represent a way to improve the level of GDP. There were used scenarios implemented on deficit spending or deficit financed by tax cuts. Mulas-Granados (2005) determined under an econometrical study that short-run revenuebased adjustments revealed more suitable chances in increasing the level of economic growth, revenue-based one proved less likely to increase income inequality, economic growth is negatively correlated with fiscal adjustments and specially if those are strong. Economic growth is positively correlated with more effective quality of the budget what appear to confirm a relationship between adjustments based on spending cuts and economic growth. Blanchard and Perotti (2002) under an econometric vector autoregressive revealed that positive government spending increase output whereas positive tax socks have a negative effect on output. Both increases in taxes and government spending have a strong negative effect on investment spending. Alesina and Ardagna (1998) on an econometric study on time series data on OECD Countries after 1960 determined that typically, a fiscal consolidation based on tax increases have short-term impacts on economy. In order to have long-term effects, it must comprise cuts in public employment, transfers and government wages. McDermott and Wescott (1996) under a research concluded that fiscal consolidation that involves the expenditure side, especially transfers and government wages, is more likely to succeed in reducing the level of public debt ratio than those based on tax consolidation. Also, the higher the influence of the fiscal consolidation, the more likely it is

Vol. 14, No. 1, Spring, pp. 163-175, ISSN 2069-8887| Management \& Marketing. Challenges for the Knowledge Society 
to succeed in reducing the level of debt ratio. Alesina and Perotti (1995) made a study over 20 OECD Countries on time series after the period of 1960 and determined that large fiscal expansions typically occur through increases in the level of expenditure, while large fiscal adjustments rely on the increase of the level of taxes. As a conclusion, expenditure based fiscal adjustments are more expansionary. Giavazzi and Peganno (1990) on a research determined that fiscal adjustments based on the spending side could be more expansionary.

On the last part of the literature review, we focus on studies that revealed the definition of a suitable management fiscal consolidation with the dynamics in the level of budgetary balance. Molnár (2012) determined the threshold for the fiscal consolidation considering four stages depending on the impact and of variation on budgetary balance per gdp ratio: a very small impact or a continuous improvement, a medium-size impact when 1 percent decrease in a single year or in two years with a minimum of 0.5 percent point in the first year and a large size impact when 1.5 percent decrease in a single year or in two years with a minimum of 1.25 percent points in each and large 2 impact when 1.5 percent point fall in a single year or in three years with less than a 0.5 percentage point deterioration in any year and considering a very large when 2 percent decrease in a single year or in 2 years with a minimum of 1.5 percentage points in each. Ahrend et. al (2006) defined under a research that fiscal consolidation involves when at least one percent point of potential gross domestic product changes in one year or at least one percentage point of potential gross domestic product changes in 2 years with at least 0.5 percentage points in the first year. Alesina and Ardagna (2009) made a research by considering a fiscal consolidation as supporting at least 1.5 percentage points movement on gross domestic product variable in one year. Alesina and Peroti (1997) defined the fiscal consolidation when at least 1.5 percent points move in the level of gross domestic product in one year or when at least 1.5 percent points of gross domestic product in 2 years. Ardagna (2009) defined the fiscal adjustments when at least 2 percent of the potential gross domestic product shifts in one year or when at least 2 percentage points of potential gross domestic product in 2 years with each more than 1.5 percentage points.

\section{Research methodology}

The study will use an econometric model in order to explain which adjustments, namely which fiscal management strategies to implement such as public-revenue adjustments or public spending adjustments in order to reach a sustainable economic growth for the next periods of time or to a decrease in the level of budgetary balance among the European countries. The study implemented an unbalanced panel model on time series from 1998 to 2018 on 28 cross sectional data represented by data collected from the European countries. The generated panel data econometric model included 588 observations and was implemented using the E-views software. The panel data revealed the individual heterogeneity among each cross-section data comprised in the model. All the macroeconomic variables that were used to generate the model were collected from the Ameco database. The econometric model would be developed with the variable of gross domestic product per capita as the dependent variable, and as independent variables having the following data: the level of direct taxes, level of indirect taxes, dynamics of public 
expenditure, dynamics of tax burden and the variance in the level of net lending for each cross sectional data involved in the model.

As far as, Figure 1 from section (a) to (e) released, the level of indirect taxes tended to increase in the last years reaching an average of among 13.3 percent on GDP in 2018 due to the policies implemented by the European member states in order to decrease the level of budgetary balance after the financial crisis. Taking into consideration the level of direct taxes, the tendency revealed also an increase, the variance in collecting such types of taxes had a medium rate of among 13,1 percent on GDP in 2018 remaining at the same time under the level of indirect taxes accrued over the European member states. Moreover, the dynamics of net lending tended to increase in the last years maintaining a negative average value of - 0.6 percent on GDP in 2018. The level of total spending decreased in the last years due to the politics taken by the European states in order to correct the deficits arose on the period of economic crisis. The medium level decrease from 50 percent in 2010 to 45 percent on GDP in 2018. As far as the level of tax burden is concerned, the medium level tended to increase in the last years with an average level of 39 percent on GDP in 2018.
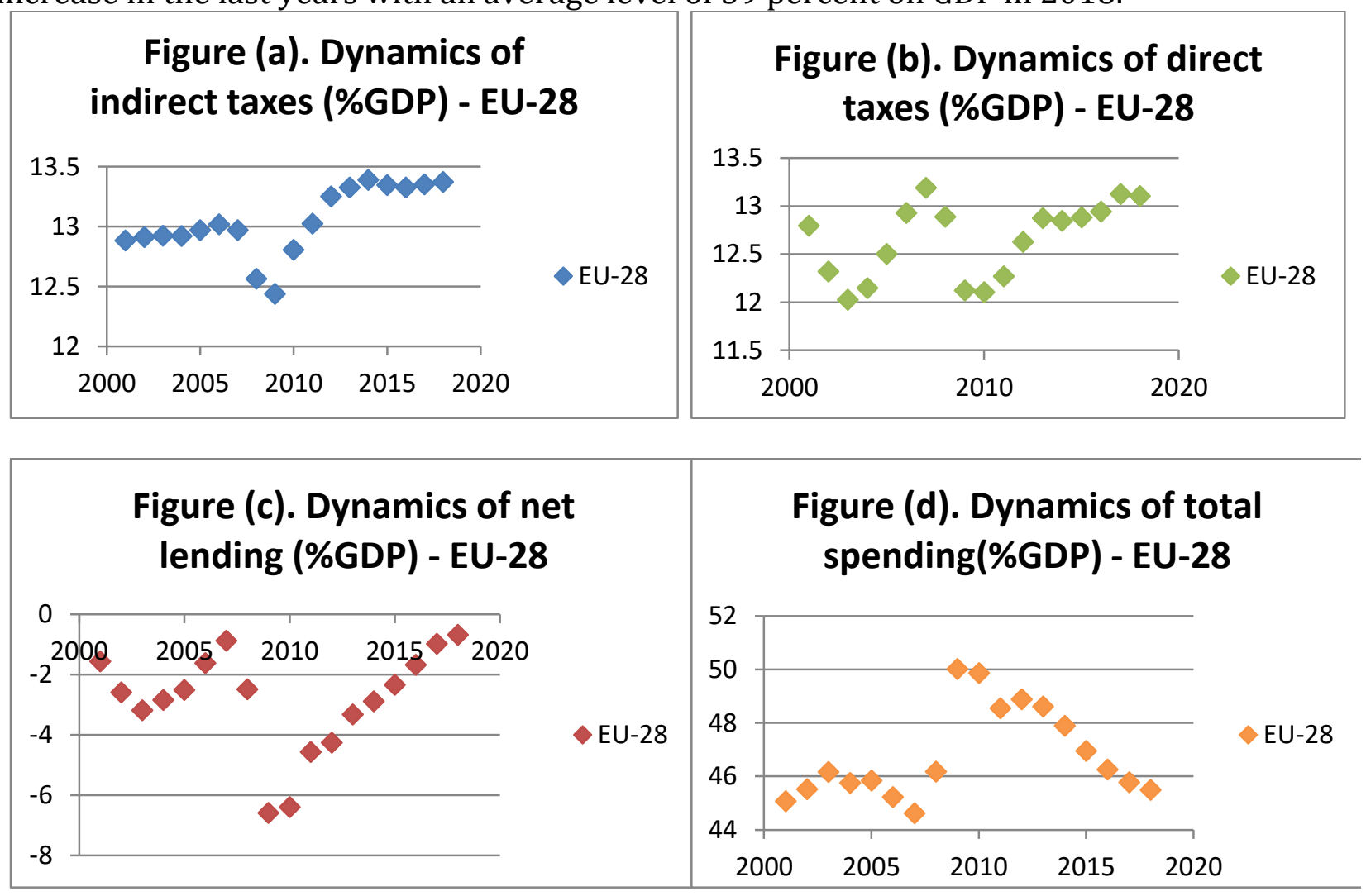


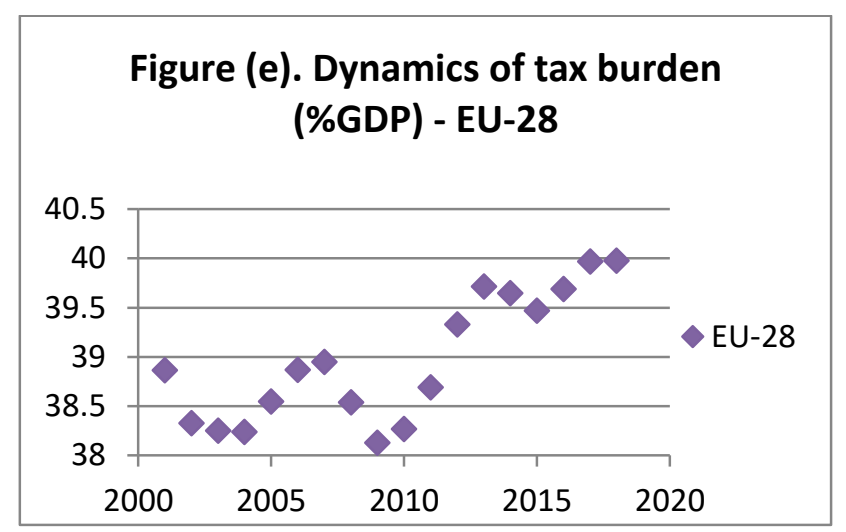

Figure 1. Dynamics in the fiscal macroeconomic variables EU-28 (1998-2018)

Source: Author's own research using time series data from Ameco Database

Table 1. Variables chosen in the panel data model

\begin{tabular}{|l|l|}
\hline Variable & Notation \\
\hline $\begin{array}{l}\text { Gross domestic product at current prices per head of population } \\
\text { expressed by the amount of real GDP per capita in purchasing power } \\
\text { parity (dependent variable) }\end{array}$ & gdppc \\
\hline Current taxes on income and wealth (direct taxes) as percent on GDP & dirtax \\
\hline Taxes linked to import and production (indirect taxes) as percent on GDP & indtax \\
\hline Total expenditure as percent on GDP & texp \\
\hline Net lending as pecent on GDP & ntlg \\
\hline Current tax burden as pecent on GDP & tbud \\
\hline
\end{tabular}

Source: Author's own research using time series data from Ameco Database

In order to reveal the interdependence and the heterogeneity between the macroeconomic variables data described above, based on Mankiw, Romer \& Weil (1992) and Macek (2014) models, we would consider a panel data model following the equation: $\operatorname{gdppc}_{i t}=\beta_{0}+\beta_{1} * \operatorname{dirtax}_{i t}+\beta_{2} *$ indtaxit $+\beta_{3} * \operatorname{texp}_{\mathrm{it}}+\beta_{4} *$ ntlg $_{\mathrm{it}}+\beta_{5} *$ tbudit $+\mu_{1} \mathrm{~d}_{1 \mathrm{i}}+\mu_{2} \mathrm{~d}_{2 \mathrm{i}}+$ $\ldots \mu_{\mathrm{n}} \mathrm{d}_{\mathrm{ni}}+\varepsilon_{\mathrm{it}}(1)$, where: gdpppc is represented by GDP per capita seen as the dependent variable, $\beta_{0}$ represents the intercept, $\beta_{1}, \beta_{2}, \beta_{3}, \beta_{4}$ represent the coefficients of the independent variables; as example of an macroeconomic variables chosen in the model, dittaxit represents the dynamics of change in direct taxes from each i sections term on each period of time $t$ included in the model, $d_{2}, d_{3}, . ., d_{i}$ represents the dummy variables, $\varepsilon_{i t}$ represent the random variables and t represents the time series. We would include dummy variables according to the following definitions: $d_{1}=1$, if $n \lg (f)<0.5, d_{1}=0$ if $n \operatorname{tg}(f)>0.5 ; d_{2}=1$, if $0.5<\mathrm{nt} \lg (\mathrm{f})<1.5, \mathrm{~d}_{2}=0$, if $0.5>\operatorname{nt} \lg (\mathrm{f})>1.5 ; \mathrm{d}_{3}=1$ if $n t \lg (\mathrm{f})>1.5 ; \mathrm{d}_{3}=0$ if $n t \lg (\mathrm{f})<1.5$ where $\mathrm{f}=(\mathrm{ntlg})_{\mathrm{t}+1}-(\mathrm{ntlg})_{\mathrm{t}}$. With reference to the above definitions, we would consider a very small influence in the dynamics of net lending if the cyclically adjusted primary balance improves only by 0.5 percent of GDP, a medium influence if the dynamics of the budgetary balance would consist in a value between 0.5 percent and 1.5 percent of GDP from one year to another and a large influence if the dynamics would consist in value of more than 1.5 percent of GDP from one fiscal year to another. 
The variation over time and the heterogeneity across countries could be seen by implementing a fixed panel data model. In this way we could explain how each chosen macroeconomic variable is changing over time from each country and from one time period to another. By implementing the fixed effect panel model there could be anticipated the unobserved terms between variables (for example the rates applied for each country for each type of tax) and would be taken into consideration the variance of each macroeconomic variables chosen for each country (variance of gdppc, variance of dirtax and other variables included in the model).

Table 2. Panel Unit Root Test

\begin{tabular}{|l|l|l|l|l|l|l|}
\hline & \multicolumn{2}{|l|}{ Level } & \multicolumn{2}{l|}{ First difference } \\
\hline Variable & $\begin{array}{l}\text { T- } \\
\text { statistic }\end{array}$ & $\begin{array}{l}\text { Observati- } \\
\text { ons }\end{array}$ & $\begin{array}{l}\text { Probabi- } \\
\text { lity }\end{array}$ & T-statistic & $\begin{array}{l}\text { Observati- } \\
\text { ons }\end{array}$ & $\begin{array}{l}\text { Probab } \\
\text { ility }\end{array}$ \\
\hline gdppc & -2.04624 & 543 & 0.0204 & -13.046 & 527 & 0.000 \\
\hline dirtax & -2.54143 & 538 & 0.0055 & -14.5887 & 513 & 0.000 \\
\hline indtax & -1.87985 & 546 & 0.0301 & -18.2599 & 520 & 0.000 \\
\hline tburd & -3.07045 & 546 & 0.0011 & -15.5712 & 523 & 0.000 \\
\hline texp & -3.46820 & 545 & 0.0003 & -16.8973 & 514 & 0.000 \\
\hline ntlg & -273798 & 545 & 0.0031 & -15.2873 & 511 & 0.000 \\
\hline
\end{tabular}

Source: Author's own calculations using E-views software.

In order to test the stationarity of the variables, we would use the panel unit Root Test with the values explained in Table 1. Due to the p-value which is less than 5 percent, variables such as dirtax, tburd, texp and ntlg are stationary at level I $(0)$ and do no have unit root. Due to the p-value which is higher than 5 percent, gdppc and the variable indtax are non-stationary at level, thus stationary at first difference I(1).

Table 3. Johansen Fisher Panel Cointegration Test

\begin{tabular}{|c|c|c|c|c|}
\hline \multicolumn{5}{|c|}{ Series : gdppc dirtax indtax tburd texp ntlg } \\
\hline \multicolumn{5}{|c|}{ Sample : 19982018} \\
\hline \multicolumn{5}{|c|}{ Included observations : 588} \\
\hline \multicolumn{5}{|c|}{ Trend assumption : Linear deterministic trend } \\
\hline $\begin{array}{l}\text { Hypothesized } \\
\text { No. of CE(s) }\end{array}$ & $\begin{array}{l}\text { Fisher Stat. * } \\
\text { (from trace test) }\end{array}$ & Probability & $\begin{array}{l}\text { Fisher Stat.* } \\
\text { (from max-eigen } \\
\text { test) }\end{array}$ & Probability \\
\hline None & 1470 & 0.0000 & 692.3 & 0.0000 \\
\hline At most 1 & 901,6 & 0.0000 & 590.7 & 0.0000 \\
\hline At most 2 & 489.2 & 0.0000 & 310.6 & 0.0000 \\
\hline At most 3 & 268.8 & 0.0000 & 191.8 & 0.0000 \\
\hline At most 4 & 137.1 & 0.0000 & 116.3 & 0.0000 \\
\hline At most 5 & 96.77 & 0.0006 & 97.77 & 0.0006 \\
\hline
\end{tabular}

Source: Author's own calculations using E-views software.

In order to reveal the relationship between variables over the analyzed time series data, we would consider the Johansen Fisher panel cointegration test as displayed in Table 2. The result disclosed a short-term or at least a medium-term relationship between the variables chosen in the econometric model due to the level of $\mathrm{p}$-value less than $5 \%$. There is no cointegrated equation between variables which would reject the null hypothesis that variables are cointegrated. 
Table 4. Ordinary Least Square Model

\begin{tabular}{|c|c|c|c|c|}
\hline $\begin{array}{l}\text { Dependen } \\
\text { Method: } \mathrm{P} \\
\text { Sample: } 1 \\
\text { Periods in } \\
\text { Cross-sect } \\
\text { Total pan }\end{array}$ & $\begin{array}{l}\text { le : gdppc } \\
\text { ast Squares } \\
18 \\
21 \\
\text { cluded: } 28 \\
\text { lanced) obse }\end{array}$ & 585 & & \\
\hline Variable & Coefficient & Std. Error & t-Statistic & Probability \\
\hline dirtax & 0.690432 & 0.028664 & 24.08711 & 0.0000 \\
\hline indtax & -4.903610 & 0.650818 & -7.534535 & 0.0000 \\
\hline tburd & 4.661877 & 0.388339 & 12.00467 & 0.0000 \\
\hline texp & 1.019826 & 0.240318 & 4.243655 & 0.0000 \\
\hline ntlg & 1.875031 & 0.478210 & 3.920933 & 0.0000 \\
\hline $\mathrm{c}$ & -63.90082 & 10.4264 & -6.090060 & 0.0000 \\
\hline $\begin{array}{l}\text { R-Squarec } \\
\text { Adjusted } \\
\text { F-statistic } \\
\text { Prob(F-St }\end{array}$ & $\begin{array}{l}395 \\
\text { ed } 0.679653 \\
41 \\
0.000000\end{array}$ & & & \\
\hline
\end{tabular}

Source: Author's own calculations using E-views software.

As far as Ordinary Least Square Model is considered, the probability of less than 5 percent for the variables represented by dirtax, indtax, tburd, texp, ntlg reveal the fact that those variables are significant to explain the evolution of gdppc. Thus, the dynamics of indtax reveal a negative relationship on the evolution of gdppc. The R-Squared value indicated 68,23 percent which revealed a significant influence but the model would not include the individual heterogeneity between the cross sectional due to the fact that it explains the influence of the variables among periods of time but not across cross sectional data.

Table 5. Fixed effect model

\begin{tabular}{|c|c|c|c|c|}
\hline $\begin{array}{l}\text { Dependen } \\
\text { Method: P } \\
\text { Sample: } 1 \\
\text { Periods in } \\
\text { Cross-sec } \\
\text { Total pan }\end{array}$ & $\begin{array}{l}\text { le: GDPPC } \\
\text { ast Squares } \\
8 \\
21 \\
\text { luded: } 28 \\
\text { lanced) obse }\end{array}$ & $: 585$ & & \\
\hline Variable & Coefficient & Std. Error & t-Statistic & Probability \\
\hline dirtax & -0.886747 & 0.078783 & -11.25562 & 0.0000 \\
\hline indtax & -1.307035 & 0.564018 & -2.317363 & 0.0208 \\
\hline tburd & -1.559613 & 0.483183 & -3.227791 & 0.0013 \\
\hline texp & 0.445857 & 0.389766 & 1.143909 & 0.2532 \\
\hline ntlg & 1.244773 & 0.431072 & 2.887620 & 0.0040 \\
\hline $\mathrm{d} 1$ & 1.008832 & 0.810865 & 1.244142 & 0.2140 \\
\hline $\mathrm{d} 2$ & 0.690377 & 0.773546 & 0.892483 & 0.3725 \\
\hline $\mathrm{d} 3$ & -0.112930 & 0.815702 & -0.138445 & 0.8899 \\
\hline $\mathrm{C}$ & 16.1263 & 8.575904 & 19.72111 & 0.0000 \\
\hline $\begin{array}{l}\text { R-Square } \\
\text { Adjusted } \\
\text { F-statistic } \\
\text { Prob(F-St }\end{array}$ & $\begin{array}{l}75 \\
\text { ed } 0.980719 \\
70 \\
0.000000\end{array}$ & & & \\
\hline
\end{tabular}

Source: Author's own calculations using E-views software. 
Due to the coefficient of dirtax, indtax and tax burden there would be considered a negative correlation of these variables with the evolution of the economic growth. The adjustments made on the level of total expenditure and further on on the level of net lending values revealed a positive correlation between economic growth and these variables. Foreseeing the results of dummy variables we would consider a negative relationship between dummy variable 3 and the economic growth. Other dummy variables which represent an adjustment in the budgetary balance of less than 1.5 percent from one fiscal year to another have a positive correlation with the evolution of economic growth. That revealed the fact that among European member states it is better to implement fiscal imbalances based on small impacts on the budgetary balance in order to contribute to a sustainable economic growth.

Table 6. Random effect model

\begin{tabular}{|c|c|c|c|c|}
\hline \multicolumn{5}{|c|}{$\begin{array}{l}\text { Dependent variable: GDPPC } \\
\text { Method: Panel Cross-section random effects } \\
\text { Sample: } 19982018 \\
\text { Periods included: } 21 \\
\text { Cross-sections included: } 28 \\
\text { Total panel (unbalanced) observations: } 585\end{array}$} \\
\hline Variable & Coefficient & Std. Error & t-Statistic & Probability \\
\hline dirtax & -0.428689 & 0.067076 & -6.391101 & 0.0000 \\
\hline indtax & -1.224803 & 0.550783 & -2.223747 & 0.0266 \\
\hline tburd & -1.451367 & 0.463293 & -3.132718 & 0.0018 \\
\hline texp & 0.508673 & 0.366478 & 1.388004 & 0.1657 \\
\hline ntlg & 1.237026 & 0.406938 & 3.039836 & 0.0025 \\
\hline c & 151.3655 & 10.68257 & 14.16939 & 0.0000 \\
\hline \multicolumn{5}{|c|}{$\begin{array}{l}\text { R-Squared } 0.115905 \\
\text { Adjusted R-Squared } 0.108270 \\
\text { F-statistic } 15.18133 \\
\text { Prob(F-Statistic) } 0.000000 \\
\text { Mean dependent var } 4.923588\end{array}$} \\
\hline
\end{tabular}

Source: Author's own calculations using E-views software.

In order to implement which model to generate, whether fixed effect model or Ordinary least square one, the Hausman Test would be distinguished having as null hypothesis the fact that random effect is most appropriate. Alternative hypothesis would consist under the circumstance that fixed effect is most appropriate. Due to the p-value which is less than 5 percent, the null hypothesis would be dismissed and the fixed model is more appropriate.

Table 7. The Hausman Test

\begin{tabular}{|c|c|c|c|c|}
\hline \multicolumn{5}{|c|}{$\begin{array}{l}\text { Correlated Random Effects - Hausman Test } \\
\text { Test cross-section random effects }\end{array}$} \\
\hline Variable & Fixed & Random & Var(Diff.) & Probability \\
\hline dirtax & -0.886747 & -0.428689 & 0.001708 & 0.0000 \\
\hline indtax & -1.307035 & -1.224803 & 0.014754 & 0.4984 \\
\hline tburd & -1.559613 & -1.451367 & 0.018825 & 0.4301 \\
\hline
\end{tabular}




\begin{tabular}{|l|l|l|l|l|}
\hline texp & 0.445857 & 0.508673 & 0.017612 & 0.6360 \\
\hline ntlg & 1.244773 & 1.237026 & 0.020225 & 0.9566 \\
\hline R-Squared 0.981775 & & \\
Adjusted R-Squared 0.980719 & & \\
F-statistic 929.2570 & & \\
Prob(F-Statistic) 0.000000 & & \\
\hline
\end{tabular}

Source: Author's own calculations using E-views software.

The estimation of a pooled regression model would have the null hypothesis that all dummy variables are equal to 0 . Alternative hypothesis would take into consideration the fixed effect model. Assuming that some dummy variables are different from the null value in the established econometric model, a fixed effect model was considered as the best alternative in order to explain the influence of the macroeconomic variables chosen on the explanation of the evolution of GDP and on the evolution of the public budgetary balance. Dummy variables implemented in the fixed effect model revealed the percentage of change in the dynamics of fiscal policies having as merger the value of 1 or 0 according to the parameters given for the dummy variables implemented in the panel data model above.

\section{Research results}

From the totally amount of observations, dummy variables would be implemented on the fixed effect model developed as: dummy variable 1 would allow for the dynamics of the variable ntlg of less or more than 0.5 percent from period t to period $t+1$, dummy variable 2 would refer to a difference between 0.5 and 1.5 percent on the ntlg variables dynamics and dummy variable 3 in a difference of more than 1.5 percent for the same variable from one fiscal year to another. According to the definition described above, the result revealed about 32 percent of existence in dummy variable 1, 35 percent in dummy variable 2 and approximately 33 percent consisted in dummy variable 3 . This means that among the European Countries over the period 1999-2018, assuming short periods of time for decreasing the level of debt, namely one fiscal year period, 32 percent of movements across the debt from period t to $t+1$ would consist in a very small improvement in the budgetary balance, 35 percent would consist in a medium size improvement while 33 percent would consist in a large size improvement on the budgetary balance. In the last years, public authorities of the European Countries tended to improve fiscal policies in order to decrease the huge deficits emerged from the financial crises consequences. For the determination of whether the improvement based on a decrease in the dynamics of budgetary balance consisted in a revenue-based or a expenditure-based improvement, there was considered a revenue-based adjustment when the level of tax revenues increased from the period t to $t+1$ and a expenditure-based improvement while the level of expenditure decreased on the same period. There was taken into consideration only the case of large size improvements in the public deficit consisted in a dynamics of more than 1.5 percent on ntlg variables from period $t$ to $t+1$. From the totally amount of 588 observations, 178 movements consisted in an increase or a decrease in the level of public deficit of more than 1.5 percent in the level of 
budgetary balance from one fiscal year to another. Further on, out of 178 movements, 36 percent of the improvements in budgetary balance consisted in a policy mix of increasing the level of total expenditure while the level of tax burden decreased. Moreover, 33 percent were implemented through a policy mix of increasing the level of tax burden while decreasing the level of total expenditure. Other policy mix discovered over the analyzed data where not significant to explain whether a revenue-based adjustment or expenditure-based improvement could be considered among the data over the European Countries. From the totally amount of adjustments comprised on a policy mix based on the increase in the level of total expenditure and decreasing the level of tax burden, 95 percent of them generated also the decrease of the level of budgetary balance. Thus, there was generated by using the dummy variables, that a positive improvement in the budgetary balance was implemented by using a policy mix with changes in the level of public expenditure in favor of tax burden adjustments.

\section{Conclusion}

Planning the finances, directing and allocating them to the right beneficiaries, would consist in a suitable fiscal management and distribution of the public finances. Any improvement in the budgetary balance could be generated by implementing suitable fiscal policies. Among the European countries there are different public tax systems, different types on managing the way of collecting taxes or the way of distributing the public financial resources through public expenditure. Among the developed countries would be a tendency to find specific public policies which would further on tend to decrease the level of budgetary balance or would be likely to improve the level of economic growth, to obtain a sustainable economic growth and further on to generate a suitable fiscal management system and a right distribution of public resources. Whether an expenditure-based improvement or a revenuebased improvement would generate a contradictory or an expansionary policy consist in a current scientific debate due to the tendency of fiscal consolidation improvements over the taxation system of the European countries. By generating a fixed effect panel model on time series from year 1998 to 2018 over the European countries, there was revealed that most of the adjustments that contributed to a decrease in the level of budgetary balance were made by generating an increase in the dynamics of public expenditure. Thus, taking the case of a long-run causality, there was revealed that a better fiscal management system of the public resources among the European countries consist in generating improvements in the level of spending, namely in the level of distribution of the expenses than those generated by changing the level of tax burden. 


\section{References}

Ahrend, R., Catte, P. and Price, R. (2006),"Interactions Between Monetary and Fiscal Policy: How Monetary Conditions Affect Fiscal Consolidation”, OECD Economics Working Paper No. 2006/49, available at: SSRN: https://ssrn.com/abstract=1010655 or http://dx.doi.org/10.2139/ssrn.1010655.

AMECO, (2018), "AMECO Macro-economic Database: 1998-2018”, European Commission, Brussels.

Alesina, A. and Ardagna, S. (2010), "2 Large Changes in Fiscal Policy: Taxes versus Spending", Tax Policy and the Economy, Vol. 24, pp. 35-68, available at: https://doi.org/10.1086/649828.

Alesina, A. and Ardagna, S. (2009), "Large Changes in Fiscal Policy: Taxes versus Spending", NBER Working Paper No. 15438, National Bureau of Economic Research, Inc.

Alesina, A. and Perotti, R. (1995), "Fiscal expansions and adjustments in OECD countries", Economic Policy, Vol. 10, Issue 21, pp. 205-248, available at: https://doi.org/10.2307/1344590.

Alesina, A. and Ardagna, S. (1998), "Tales of fiscal adjustment", Economic Policy, Vol. 13, Issue 27, pp. 488-545, available at: https://doi.org/10.1111/1468-0327.00039.

Alesina, A. and Perotti, R. (1997), "Fiscal Adjustments in OECD Countries: Composition and Macroeconomic Effects", IMF Staff Papers, Vol. 44, Issue 2, pp. 210-248.

Ardagna, S. (2009), "Determinants and Consequences of Fiscal Consolidations in OECD Countries", European Commission: European Economy 2009, European Commission, Brussels.

Barrios, S., Langedijk S. and Pench, L. (2010), "EU fiscal consolidation after the financial crisis. Lessons from past experiences", Economic Papers, No. 418, European Commission, Brussels.

Blanchard, O. and Perotti R. (2002), "An Empirical Investigation of the Dynamic Effects of Changes in Government Spending and Revenues on Output", Quarterly Journal of Economics, Vol.117(4), pp. 1329-1368.

Brooks, Ch. (2014), "Introductory Econometrics for Finance", $3^{\text {rd }}$ Edition, Cambridge University Press, New York, USA.

Duncombe, W. (2018), "Lectures notes in public budgeting and financial management", $1^{\text {st }}$ Edition, World Scientific Publishing Co. Inc. , New Jersey, USA.

Enders, W. (2004), „Applied Econometric Time Series Second Edition”, Wiley.

European Commission (2019), "Report on Public Finances in EMU 2018", European Commission, Brussels.

European Commission (2007), "European Economy - Public Finances in EMU 2007", No. 3, European Commission, Brussels.

Friedman, M. (1978), “The Limitations of Tax Limitation”, Policy Review (Summer), pp. 714. 
Greene, W. (2000), "Econometric Analysis", 4th Edition, Prentice Hall International, New Jersey, USA.

Gujarati, D.N. (2004), "Basic Econometrics. 4th Edition”, McGraw-Hill Inc., New York, USA.

Hamilton, J. (1994), „Time Series Analysis”, Princeton University Press, Princeton, New Jersey.

Lutkepohl, H. and Mekus K. (2004), "Applied Time Series Econometrics", Cambridge University Press, New York, USA.

Macek, R. (2014), The Impact of Taxation on Economic Growth: Case Studies of OECD Countries", Review of Economic Perspectives, Vol. 14, Issue 4, pp. 309-328., available at: https://doi.org/10.1515/revecp-2015-0002.

Mankiew, G., Romer, D., Weil, D. (1992), "A Contribution to the Empirics of Economic Growth", The Quarterly Journal of Economics, Vol. 107(2), pp. 407-437.

McDermott, C. and Wescott, R. (1996), "An Empirical Analysis of Fiscal Adjustments", IMF Working Paper, No.WP/96/59, pp. 1-26.

Molnár, M. (2012), "Fiscal consolidation: What factors determine the success of consolidation efforts?”, OECD Journal: Economic Studies, Vol. 2012/1, available at: https://dx.doi.org/10.1787/eco_studies-2012-5k8zs3twgmjc.

Mihóková , L. (2017), "Fiscal Consolidation Start and its Determinants Analysis within European Member Countries", Montenegrin Journal of Economics, Vol. 13, No. 3, pp. 135-147.

Mirdala, R. (2014), "Period of fiscal consolidation in selected European countries", Procedia Economics and Finance, Vol. 15, pp. 137-145, available at: https://doi.org/10.1016/S2212-5671(14)00462-6.

Mountford, A. and Uhlig, H. (2009), "What are the effects of fiscal policy shocks?", Journal of Applied Econometrics, Vol. 24, Issue 6, pp. 960-992, available at: https://doi.org/10.1002/jae.1079.

Mulas-Granados, C. (2005), "Fiscal adjustments and the short-term trade-off between economic growth and equality", Revista de Economía Pública, Vol. 172(1), pp. 61-92.

Niskanen, W. A. (1978), "Deficits, Government Spending, and Inflation: What Is the Evidence?", Journal of Monetary Economics, Vol. 4 (3), pp. 591-602.

Niskanen, W. A. (2002), "Comments. In J. A. Frankel and P. R. Orszag (eds.) American economic policies in the 1990s", Mass.: MIT Press, Cambridge.

Pindyck, R. and Rubinfeld, D. (2000), "Econometric Models and Economic Forecasts", $4^{\text {th }}$ Edition, McGrow-Hill Inc., New York, USA.

Pindyck, R. and Rubinfeld, D. (1998), "TSP Handbook to Accompany Econometric Models and Econometric Forecasts", $4^{\text {th }}$ Edition, McGrow-Hill Inc., New York, USA.

Wagner, R. E. (1976), "Revenue Structure, Fiscal Illusion, and Budgetary Choice", Public Choice 25 (Spring), pp. 30-61. 